UDK 630*43(497.6 Konjic)“2009/2013“

\title{
ANALYSIS OF THE FOREST FIRES IN THE KONJIC MUNICIPALITY IN THE PERIOD OF 2009 - 2013 YEAR
}

\author{
Analiza šumskih požara na području općine Konjic u periodu 2009 - 2013 godine
}

\author{
Samir Alikadić ${ }^{1}$, Mirza Dautbašić ${ }^{2}$, Osman Mujezinović ${ }^{2}$, Kenan Zahirović ${ }^{3}$
}

\begin{abstract}
Forests as one of the largest renewable sources in nature, are extremely important for human survival. They cover about a quarter of the Earth's surface and are the lungs of all living beings. Rapid technological development has significantly improved the life of a man, but also made a great contribution to the destruction of the natural balance, and reducing biodiversity.

They represent a significant social wealth not only by producing precious and for its quality values in many ways irreplaceable wood material, edible and medicinal plants, but also because its existence is a very positive impact on the protection and improvement of the environment, regulation of climate and water regime, reducing damage from erosion, flood and spate, development of recreation, tourism, hunting and many other economic activities. Fires are one of the strongest and most dangerous agents that man were served in suppressing forest since ancient times, but unfortunately still used today. In many parts of world man suppresses forest and brush with fires, creating a short-term favorable conditions for its economy.

Research that are the subject of this paper is an analysis of the volume of forest fires in the period 2009-2013 year in the municipality of Konjic. The conducted analysis in this area in the period 2009-2013 year recorded 37 fires. Of that number, 20 fires were in the category of crown-fires and 17 ground-fires. The largest number of fires was 14 in 2011, with 310 hectares of fire-affected areas, while the lowest number was recorded in 2010, only three fires and burnt area amounted to 7 ha.
\end{abstract}

Key words: forest fires, municipality Konjic, 2009 - 2013 year.

\section{INTRODUCTION - Uvod}

There are many factors that have destructive impact on forest ecosystems but one of the most devastating long-term consequences of is a fire which is manifested through the fires. According to PYNE ET AL. (1996) fires are among the most important natural destabilizing factors. Fires not only destroy the forest but destructive of the pedosphere leaving the soil without humus, which is a reservoir of nutrients and

\footnotetext{
${ }^{1}$ Forestry „Prenj“ d.d. Konjic

${ }^{2}$ University of Sarajevo, Faculty of Forestry

${ }^{3}$ Public enterprise "Šumsko-privredno društvo Zeničko-dobojskog kantona" d.o.o., Zavidovići
} 
carbon. The appearance of the forest after the fires is changed, remaining trees are susceptible to infections that further spread on the surrounding forest (mostly bark beetles and wood decaying fungi).

Ecological problems have wider significance than those who are directly visible. For a successful re-cultivation of burnt areas is necessary to an understanding of these processes, because the ecological effects of fires can be extremely complex, which is in connection with the accompanying negative, usually less predictable consequences (WHELAN, 1995).

At the same time forests are exposed to negative effects of wind storms, snowfalls, insects and other diseases that cause a variety of damage. The greatest damage to our forests inflict forest fires, which mainly causes man. Up to $90 \%$ of forest fires are caused by human activities, primarily through the uncontrolled use of fire during the cleaning of forests and forest lands for agriculture and industrial development (NIKOLOV, 2006). According to its destructive effect, forest fires as abiotic factors are particularly important (JURJEVIĆ, 2004). From forest fires the most vulnerable are coniferous forest, then the forest near settlements and roads, as well as places where the wood mass is harvested.

A lot has been made on protection of forests against the fires, but is still insufficient, it is necessary to improve the methods and to take additional measures to prevent the occurrence or spread of the fires. The more preventive measures we have, there will be less fires, and easier access to their extinguishing and much less damaging consequences (JURJEVIĆ, 2004).

USČUPLIĆ (2001) states that the fires are widespread phenomenon, and when they occur in the forest, they have not only economic but also ecological effects. Hazardous economic impact is just one of the problems and there are far away more harmful ecological effects, which are directly manifested. For the re-cultivation of burnt areas is necessary to understanding these processes, because the ecological effects of fires can be extremely complex, which is in connection with the accompanying negative, usually less predictable consequences (WHELAN, 1995).

Forest fires in the forests of the world inflict great damage, depending on age and area of forest tree species, and vegetation and the type of fire and his strength. The vulnerability of certain areas from the forest fires is different. There are allocated three very vulnerable areas in the world: the Mediterranean, the area of North American pine forests and area of the African savannas (JURJEVIĆ ET AL., 2009).

FLOLLIOTT (1988) believes that the impact of fires on ecosystems depends on the nature of fire, fire-affected habitat characteristics and characteristics of of the natural inventories exposed to fire.

According to GLAVAŠ (2005) it is estimated that in the world per year is burned about 70 million hectares under various vegetation. Forest fires can be classified among the most powerful forces of nature, which in its crusade destroy the people material goods and natural resources.

The burning of biomass and humus release huge amounts of coal in the form of $\mathrm{CO}_{2}$ and go to the atmosphere. Fires destroy the seeds of useful species of trees, 
shrubs and ground vegetation that prevents regeneration. Fires are a global problem, over 10 million hectares of forests are lost globally each year (MLADINEO, 2001). According to forecasts, fires in vegetation which include fire clearing in tropical areas, will reduce forest areas in the world by $50 \%$ in 2030. In Europe every year is burned more than $10.000 \mathrm{~km}^{2}$ of different vegetation, and in Russia and North America up to $100.000 \mathrm{~km}^{2}$. About $20 \%$ of $\mathrm{CO}_{2}$ emissions is caused by forest fires (KÜHRT ET AL., 2001).

FAO has made a global assessment of the area that was hit by the fires in 2000, which amounts to 350 million hectares, of which most of them were covered by forests and afforested areas. In the same review is indicated that people are the biggest cause of fires in all regions. The most common causes of forest fires are: cleaning soil especially for moving crops, other agricultural activities, and maintaining grasslands in order to fed to livestock, drawing non-timber forest products, industrial development, resettlement, hunting, carelessness and setting a fire purposely. The review concludes that the prevention and suppression of fires is often difficult, and least due to the unclear lines of institutional responsibility, and conflicting policies and laws.

Earlier researches conducted by FAO about laws of forests fires are mainly focused on international agreements on forest fires. The initial review of existing national legislation on fires was also made at the same time, and there is a need for "deeper analysis and evaluation".

In the accordance with the recommendations of the International Summit of protection against wildfires in 2003, the Ministerial Meeting on sustainable maintenance of forests in 2005, and the meeting of the FAO Committee on Forests from 2005 (COFO), FAO coordinated the process that resulted in the 2007 with Guidelines on voluntary fires management - the principles and strategic actions (FAO guidelines). The guidelines prescribe a number of priority principles aimed at, among other things, to support the establishment of legal and regulatory requirements for a holistic approach to managing fire. The guidelines underline the importance of truly appropriate legal framework for the effective management of the fires, and prescribe certain principles which can guide legislators in this regard.

According to to the latest data at EFFIS (The European Forest Fire Information System), Bosnia and Herzegovina in 2012 was affected with more fires than the last five years together. According to these data, $58 \%$ of the total burnt area are forests and forest lands (Table 1). 
Table 1. Distribution of areas affected by the fires by type of land in Bosnia and Herzegovina (ha)

Tabela 1. Distribucija površine zahvaćene požarima po tipu zemljišta u BiH (ha)

Type of land

Forests/forests lands

Other natural lands

Agricultural lands

Artificial lands

Other lands

Total
Area (ha)

51. 274,79

$25.931,27$

$10.479,92$

4,15

6,87

$\mathbf{8 7 . 6 9 7 , 0 1}$
$\%$ from total area

58,47

29,57

11,95

0,00

0,01

100,00

According to the data of the Federal Administration of Forestry, in Federation of Bosnia and Herzegovina was registered 1082 forest fires, burned area was over 43,000 hectares and estimated the damage to the timber stock and planting material up to approximately 50 million BAM. Fires in low vegetation, forests and wide areas are enormous and sustained threat to human life, health and life, economic development and human environment.

The most vulnerable are pine cultures and stands, then other conifer cultures, followed by oak coppice forests and shrubs (Image 1 and 2). As for the economic, but also because of the environmental effects generated as a result of fire, it is necessary to understand this process, and improvements in the forestry profession through continuing education of employees and the local population, primarily the youngest population as a way of reducing the risk from fire (VESELINOVIĆ \& MILENKOVIĆ, 2007). According to MARGALETIĆ \& MARGALETIĆ (2003) the most common cause of forest fires is the man who intentionally or negligently causes forest fires and the very small number of fires occur by a lightning strike or railways. Previous findings indicate that most of the fire was initiated by lighting the fire on the abandoned weedy and agricultural land (MAMUT, 2011). 


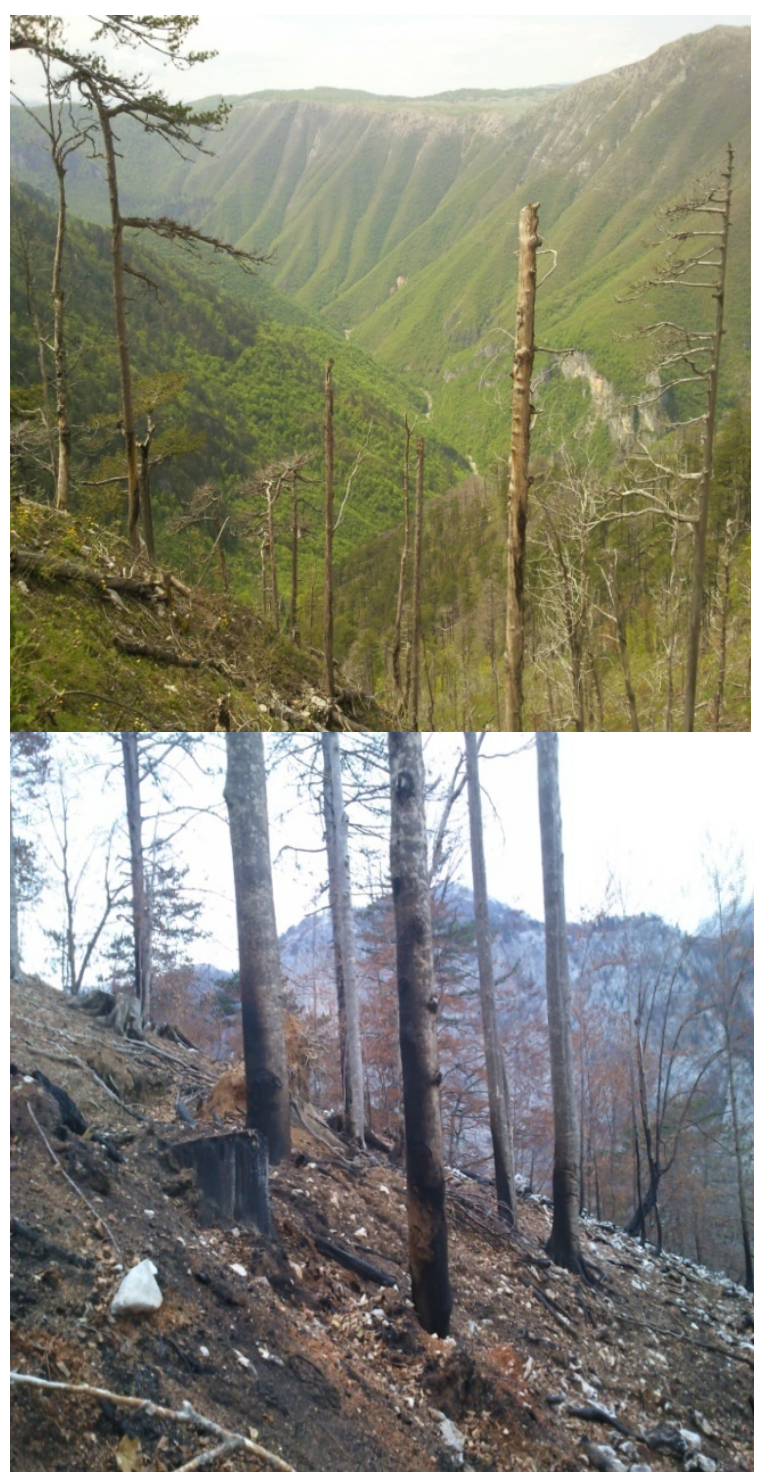

Image 1 and 2. Burnt areas in Konjic municipality in coniferous and broadleaves stands Slika 1 i 2. Opožarene površine na području općine Konjic u četinarskim i lišćarskim sastojinama

As part of many measures aimed at reducing the number of fires in the forest and on forest land, takes a prominent place and propaganda among the local population and tourists. Insufficient is emphasis on the dangers and harmful effects from fire in public space, insufficient familiarity of the local population, especially visitors. There is a lack of advertising materials and lectures. Forestry profession that 
is often best place to address these problems, especially when it comes to forest and forest lands, is not sufficiently represented, and often marginalized in prevention, especially in firefighting on open space, so that its role is mainly reduced to the assessment damages (NODILO, 2003). The fire can not spread if flammable material contains more than $25 \%$ moisture, and if the air temperature is not too low. In case of high air temperature and humidity covers less than $10 \%$ fire very easily and rapidly expanding (VULETA, 2001).

\section{MATERIAL AND METHODS - Materijal i metode}

Research that are the subject of this paper was performed analysis of forest fires in the period 2009-2013 year in the municipality of Konjic.

This research was conducted in the area of the forest management area "Konjičko" which is also the administrative border of the municipality of Konjic. The forest management area "Konjičko" geographically belongs to the sub-Mediterraneanmountainous area which extends in the higher parts of the Mediterranean-dinar area, mostly above $800 \mathrm{~m}$, to the highest regions that pass $2000 \mathrm{~m}$ above sea level.

According to orographic characteristics is an extremely mountainous area with widely represented subalpine belt. Mediterranean dinar territory covers parts of Dinarides, which are influenced by Mediterranean climate, including parts of Bosnia and Herzegovina.

According to its geographical position, the forest management area "Konjičko" is located between $17^{\circ} 45^{\prime}$ and $18^{\circ} 18^{\prime}$ north latitude, and $42^{\circ} 28$ 'and $43^{\circ} 53^{\prime}$ longitude (east of Greenwich).

In this area there are three mountain massifs: Prenj, Visočica and Bitovnja, then in the border areas of the field and Ivan mountain, Pogorelica and Borašnica, but largely in this area interfere the slopes of Bjelašnica, Treskavica and Crvnja.

In order to realize the a task of research, which is to establish the intensity of forest fires (five-year period, from 2009 to 2013 year) in Konjic municipality was registered the data by type of fire, the type of forest and soil, and management classes to which these fires was reported, then the causes of the fires. Determining statistical differences in the number of of fires by type of fires in the municipality of Konjic was performed using $\chi^{2}$ test $(\mathrm{p}=0.05)$. This analysis was performed using the statistical program PHStat2 (version 2.70), (Multiple options - Sample Tests, Chi - Square Test).

\section{RESULTS - Rezultati istraživanja}

In Table 2 is presented the number of fires and burnt areas in the municipality of Konjic in period of from 2009 to 2013 year. 
Table 2. Number of fires and burnt areas in the period 2009 to 2013 in the municipality of Konjic

Tabela 2. Broj požara i opožarena površina u periodu 2009.-2013.godine na području općine Konjic

\begin{tabular}{|c|c|c|c|c|c|c|}
\hline \multirow{2}{*}{ Year } & \multicolumn{3}{|c|}{ Number of fires } & \multicolumn{3}{c|}{ Area (ha) } \\
\cline { 2 - 7 } & $\begin{array}{c}\text { Ground- } \\
\text { fires }\end{array}$ & $\begin{array}{c}\text { Crown- } \\
\text { fires }\end{array}$ & Total & $\begin{array}{c}\text { Ground- } \\
\text { fires }\end{array}$ & $\begin{array}{c}\text { Crown- } \\
\text { fires }\end{array}$ & Total \\
\hline $\mathbf{2 0 0 9}$ & 7 & 2 & 9 & 55,50 & 11,70 & 67,20 \\
\hline $\mathbf{2 0 1 0}$ & 3 & 0 & 3 & 7,00 & 0,00 & 7,00 \\
\hline $\mathbf{2 0 1 1}$ & 8 & 6 & 14 & 95,30 & 214,90 & 310,20 \\
\hline $\mathbf{2 0 1 2}$ & 0 & 7 & 7 & 0,00 & 5159,30 & 5159,30 \\
\hline $\mathbf{2 0 1 3}$ & 2 & 2 & 4 & 1,30 & 1,20 & 2,50 \\
\hline TOTAL & $\mathbf{2 0}$ & $\mathbf{1 7}$ & $\mathbf{3 7}$ & $\mathbf{1 5 9 , 1 0}$ & $\mathbf{5 3 8 7 , 1 0}$ & $\mathbf{5 5 4 6 , 2 0}$ \\
\hline
\end{tabular}

Another factor that affects the occurrence and spread of fires is a type of forest, and its impact on the occurrence and spread of fire. Table 3 presents the number of fires and burnt area affected by breeding forest types and the types of fires for a period of 2009-2013 year.

Table 3. Burnt areas by forest types and land in the period 2009-2013 year

Tabela 3. Opožarena površina po tipu šume i zemljišta u periodu 2009 - 2013 godine

\begin{tabular}{|c|c|c|c|c|c|c|}
\hline \multirow{2}{*}{ Type of forests } & \multicolumn{3}{|c|}{ Number of fires } & \multicolumn{3}{c|}{ Area (ha) } \\
\cline { 2 - 7 } & $\begin{array}{c}\text { Ground } \\
\text {-fires }\end{array}$ & $\begin{array}{c}\text { Crown- } \\
\text { fires }\end{array}$ & Total & $\begin{array}{c}\text { Ground- } \\
\text { fires }\end{array}$ & $\begin{array}{c}\text { Crown- } \\
\text { fires }\end{array}$ & Total \\
\hline Natural forests & 11 & 16 & 27 & 114,20 & 3725,60 & 3839,80 \\
\hline Coniferous forest & 5 & 7 & 12 & 46,90 & 1565,60 & 1612,50 \\
\hline Deciduous forest & 5 & 1 & 6 & 65,80 & 1940,50 & 2006,30 \\
\hline Mixed forests & 1 & 1 & 2 & 1,50 & 219,50 & 221,00 \\
\hline Coppice forests & 7 & 1 & 8 & 41,40 & 1083,80 & 1125,20 \\
\hline Forest land & 0 & 0 & 0 & 0,00 & 577,70 & 577,70 \\
\hline $\begin{array}{c}\text { Other land under } \\
\text { forests }\end{array}$ & 1 & 0 & 1 & 2,00 & 0,00 & 2,00 \\
\hline Other areas & 1 & 0 & 1 & 1,50 & 0,00 & 1,50 \\
\hline TOTAL & $\mathbf{2 0}$ & $\mathbf{1 7}$ & $\mathbf{3 7}$ & $\mathbf{1 5 9 , 1 0}$ & $\mathbf{5 3 8 7 , 1 0}$ & $\mathbf{5 5 4 6 , 2 0}$ \\
\hline
\end{tabular}

In continuation of this work was determined statistical significance in the number of of fires for the municipality of Konjic in the period of 2009-2013 year. The null hypothesis were: "There are no statistically significant differences in the number of of fires, by type of fires, in the municipality of Konjic in the period 2009-2013 year". The results of the tests are presented in Table 4. 
Table 4. Determination of statistical significance in the number of of fires by type of fires in the period 2009-2013 year in the municipality of Konjic

Tabela 4. Utvrđivanje statističke značajnosti u broju požara po vrstama požara u periodu 2009-2013 godine na području općine Konjic

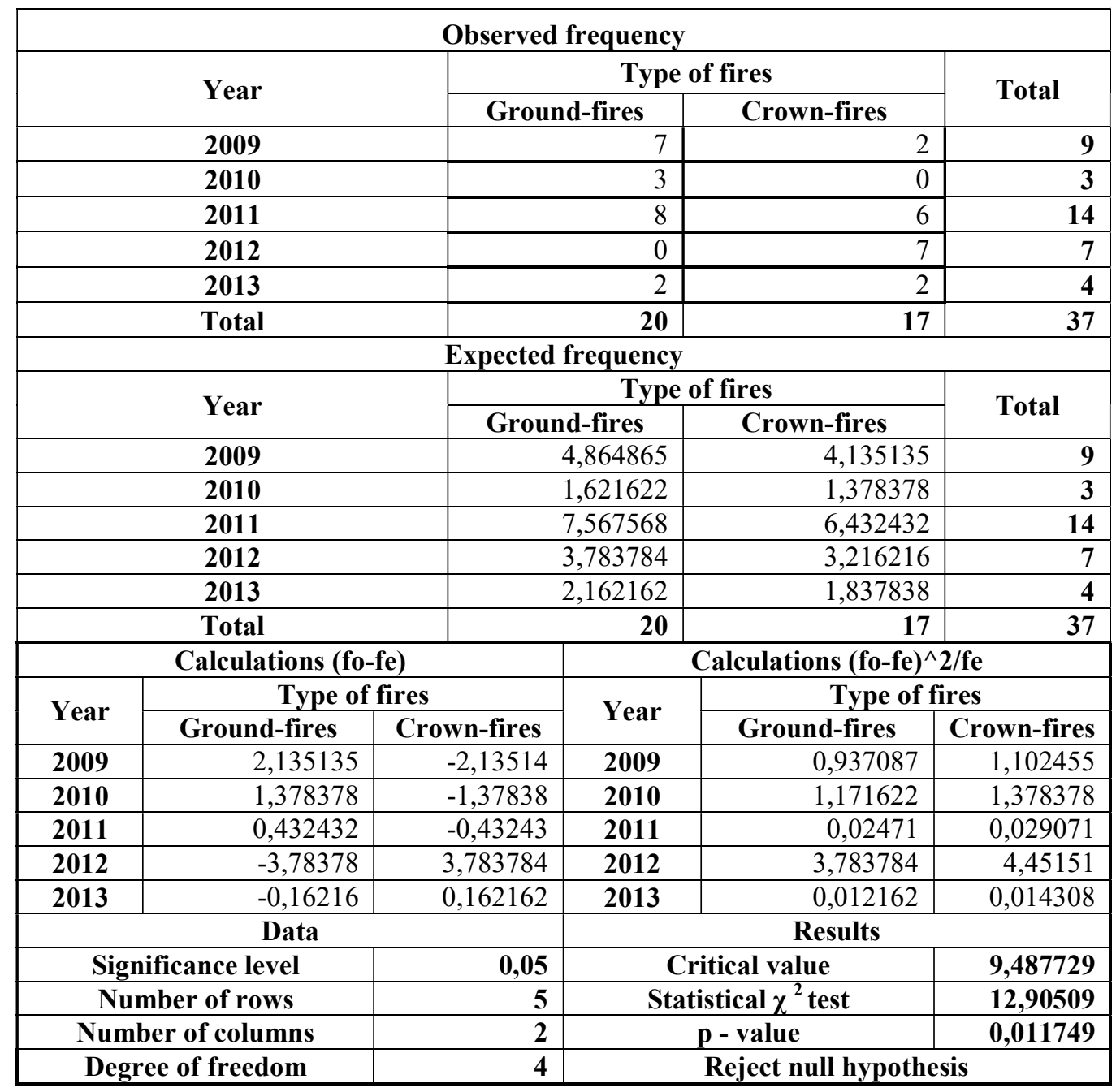

In fact, on occurrence of fires affect many factors, and in Table 5 is presented the number of fires and burnt areas, by causes of fires in the period of 2009-2012 year. 
Table 5. The causes of fires in Konjic municipality from 2009 to 2012 year

Tabela 5. Uzroci nastanka požara na području općine Konjic 2009 - 2012 godine

\begin{tabular}{|c|c|c|c|c|c|c|}
\hline \multirow{2}{*}{$\begin{array}{c}\text { The cause of } \\
\text { fire }\end{array}$} & \multicolumn{3}{|c|}{ Number of fires } & \multicolumn{3}{c|}{ Area (ha) } \\
\cline { 2 - 7 } & $\begin{array}{c}\text { Ground- } \\
\text { fires }\end{array}$ & $\begin{array}{c}\text { Crown } \\
\text {-fires }\end{array}$ & Total & $\begin{array}{c}\text { Ground- } \\
\text { fires }\end{array}$ & $\begin{array}{c}\text { Crown- } \\
\text { fires }\end{array}$ & Total \\
\hline Arson & 1 & 6 & 7 & 10,00 & 3975,90 & 3985,90 \\
\hline Inattention & 17 & 9 & 26 & 147,80 & 1417,00 & 1557,80 \\
\hline Natural causes & 0 & 0 & 0 & 0,00 & 0,00 & 0,00 \\
\hline $\begin{array}{c}\text { Unknown } \\
\text { causes }\end{array}$ & 0 & 0 & 0 & 0,00 & 0,00 & 0,00 \\
\hline TOTAL & $\mathbf{1 8}$ & $\mathbf{1 5}$ & $\mathbf{3 3}$ & $\mathbf{1 5 7 , 8 0}$ & $\mathbf{5 3 9 2 , 9 0}$ & $\mathbf{5 5 4 3 , 7 0}$ \\
\hline
\end{tabular}

To determine which human factor most influences the emergence and spread of forest fires, it was examined the cause of fires, and it is characterized as fires that occurred by carelessness (agricultural works, communications, etc.). In Table 6 are presented information on the number of fires and burned area incurred by carelessness, for the period 2009-2012 year. Information about the causes of fires in 2013 were not considered because they were not available at time of writing the work.

Table 6: Information on fires in Konjic municipality in the period from 2009 to 2012 year caused by carelessness (by number and type of fires)

Tabela 6: Informacije o požarima na području općine Konjic u periodu 2009 - 2012 godine koji su uzrokovani nepažnjom (po broju i vrsti požara)

\begin{tabular}{|c|c|c|c|c|c|c|}
\hline \multirow{2}{*}{ The cause of fire } & \multicolumn{3}{|c|}{ Number of fires } & \multicolumn{3}{c|}{ Area (ha) } \\
\cline { 2 - 7 } & $\begin{array}{c}\text { Ground- } \\
\text { fires }\end{array}$ & $\begin{array}{c}\text { Crown- } \\
\text { fires }\end{array}$ & Total & $\begin{array}{c}\text { Ground- } \\
\text { fires }\end{array}$ & $\begin{array}{c}\text { Crown- } \\
\text { fires }\end{array}$ & Total \\
\hline $\begin{array}{c}\text { Agricultural } \\
\text { activities }\end{array}$ & 9 & 5 & 14 & 91,30 & 1285,10 & 1376,40 \\
\hline Forest activities & 0 & 0 & 0 & 0,00 & 0,00 & 0,00 \\
\hline $\begin{array}{c}\text { Industrial } \\
\text { activities }\end{array}$ & 0 & 0 & 0 & 0,00 & 0,00 & 0,00 \\
\hline Communications & 1 & 4 & 5 & 1,00 & 124,90 & 125,90 \\
\hline Vistitors of forests & 0 & 0 & 0 & 0,00 & 0,00 & 0,00 \\
\hline Other & 0 & 0 & 0 & 0,00 & 0,00 & 0,00 \\
\hline TOTAL & $\mathbf{1 0}$ & $\mathbf{9}$ & $\mathbf{1 9}$ & $\mathbf{9 2 , 3 0}$ & $\mathbf{1 4 1 0 , 0 0}$ & $\mathbf{1 5 0 2 , 3 0}$ \\
\hline
\end{tabular}




\section{DISCUSSION - Diskusija}

Forests are significant social wealth not only because they produce valuable and for its high-quality characteristics, in many ways irreplaceable, wood raw material, edible and medicinal plants, but also because their existence have a positive impact on protection and improvement of the environment, regulation of climate and water regime, to help minimize damage from erosion, flood and flooding, development of recreation, tourism, hunting and many other economic activities.

In recent years, the stability of this valuable resource is increasingly undermined, and one of the main causes of the degradation changes are forest fires (ŠPANJOL ET AL., 2011). Fires are a widespread phenomenon, and if they occur in the forest then have not only economic but also ecological impacts. With their effect almost instantly disappear huge forest complexes, which brings change in the general appearance of the whole areas where they raged. From the rich and stable forest they generate the ruins and the bare surfaces, and to forest sites bring enormous damage and disruption of business, which, in many cases, is difficult to repair. Knowing the critical period of the appearance of forest fires, characteristics of overgrows and climatic conditions of the site, allows us to organize the efficient protection of forests against of fires (USČUPLIĆ, 2001).

According to ROSAVEC (2009) with the relief, geological substrate and soil, on formation of forest fires and the size of the burnt area has the greatest significance state of vegetation and climate conditions.

Analysis of forest fires was performed for the municipality of Konjic, based on data established by the Forestry "Prenj" dd Konjic, in the period of 2009-2013 year. At the research facility (Konjic municipality) was established the the number of fires, burnt area, type of of fires, surface affected by the type of forest and land.

With performed analysis in this area in the period 2009-2013 the year was recorded 37 fires. Of that number, 20 fires were in the category of crown-fires and 17 ground-fires. The largest the number of fires was in 2011 and it was 14 fires, with 310 hectares of fire-affected areas, while the lowest number was recorded in 2010, only three fires and burnt area was 7 ha. However shall not be ignored the potential danger, because every fire represents a specific disaster, damage and loss (GLAVAŠ, 2003). The largest surface affected is derived from the forest fires that have been in 2012, while the least fire-affected area was recorded in 2013, only 2,5 ha (Table 2).

Viewed according to the research results (Table 2) it can be seen that a large number of ground-fires in relation to crown-fires. However, the surface affected is much higher resulting harmful effects crown-fires. Observed according to the years of harmful effects forest fires shows that the largest number of ground-fires was recorded in 2011 and in 2012 was recorded the only crown-fires. The highest recorded fired area in the reporting period was in 2012, when fired area was 5159,3 ha and was recorded 7 fires.

A large number of factors that influence the spread of fires, and among them is certainly the type of forest, and its silvicultural form in which they occur. According 
to the research (Table 3) the largest number of fires and observed by type of vegetation were recorded in coniferous forests (12). Of this number, (5) fires is in the category of ground-fires and seven of crown-fires. A significant number of fires registered in the category ground (coppice) forest (8) and 7 ground-fires and one crown-fire. Type of fuel material determines the intensity and fire behavior. If we look at fires by type of wood forests are differently vulnerable to forest fires. Coniferous stands of are much more susceptible to ignition and burning without the presence of resins and ethereal oils. This is followed by mixed stands and culture conifers, hardwoods and finally stands of hardwoods. From tree species the most vulnerable are black and white pine, spruce and fir, and broadleaf species oak is the most sensitive. The risk of to forest fires is much greater among younger trees.

Similar results during the research of occurrence and spread of fires has got JURJEVIĆ ET AL. (2009). On our site of research is considerably higher percentage of of hardwood forest which resulted in greater burnt area (2006,3 ha) compared to the conifer forest (1612,5 hectares). Statistically significant differences in the number of fires by type were found in the area of research for this period of observation (Table 4). Many studies show that climate and intensity of to forest fires are closely linked, some believe that global warming will cause it to circumpolar forests be irreversibly damaged from forest fires which can not be controlled.

DIMITROV according to SWETNAM (1993), claims that it is true that forest fires and climate are intimately linked and that during the past fire regime has responded on changes in the climate. Hypothesis of Flannigan and others is that the recent warming is an analogue of future warming and future forest fires can react like those in the recent history of the fires (DIMITROV, 2000). NETOLICKI ET AL., according to MLADINEO (2001) states that fires a large worldwide problem, because in them each year in the world lost more than ten million hectares of forest.

Forest fires not only destroy wood mass, larger forest fires cause psychological restlessness with the population. Forest fires destroyed crops, homes, infrastructure (bridges, wires, etc.), and sometimes get hurt and human lives. In ten year period from 1998-2008 in fires or from the effects of fires in Croatia were killed 428 people, of which the darkest year was 2007, when was lost his life 51 human (MAMUT, 2011).

To determine which factors most frequently affect the spread of fires, or whether they are caused by natural phenomena or human activity, fires are divided on the causes of origin, their numbers by type of fires and burned area in the past. The largest number of fires is caused by carelessness (a total of 26 of fires), while most burned area was arson (3985,90 ha) (Table 5). Studies of other authors show that in most cases the cause of forest fires is human. According to research by other authors largest number of registered forest fires is caused by human, while in many cases the cause of of fires remains unknown (DUCIĆ ET AL., 2007).

According to MARGALETIĆ\&MARGALETIĆ (2003) on the Croatian territory during the period of 2000 year the largest number of forest fires according to the way of cause is made with carelessness and negligence, a little less is made intentional and 
from lightning strike. The human factor was and this time the most common cause of fires (burning the weeds on agricultural areas, discarding cigarette ends, burning uncontrolled waste dumps).

According to MAMUT (2011) number of fires in the Republic of Croatia in the period from 1998-2008 year by the way of cause of fires $75 \%$ was carelessness, $18 \%$ undetermined, $4 \%$ intentional, $2 \%$ children play and $1 \%$ natural cause. Knowing the cause of and the behavior is of great importance for the organization of preventive action, timely and effective action fire fighting .

The largest number of fires is caused by agricultural work (Table 6), as well as the size of the burnt areas, most frequently in the spring time when cleaning agricultural land by the local population. Previous studies indicate that the majority of fires was initiated burning fire on the abandoned weedy and agricultural lands, from where they spread to forest areas (MAMUT, 2011).

Forest fires influence on the loss of organic matter from the soil which causes the return of carbon to the atmosphere and reinforcing global warming. At the fire site reported the occurrence of landslides and various forms of strong erosion. Forests which are affected by forest fires or damaged and physiologically weakened trees become a source of outbreak of insect pests and plant diseases.

The total damage from forest fires in addition to damages caused by the destruction of the wood mass includes firefighting costs, costs of remediation and restoration of damaged forests. The total damage from forest fires, including costs of amendments to planning documents such as the basics of forest management, protection programs and the development of protected natural resources, development of remediation programs for burnt areas and so on. One of the greatest damage is the time (decades) it takes to forest restoration and again to fulfill its function.

Unfortunately, the consequences of forest fires manifest many years after the fires on: biodiversity, the disappearance of rare, endangered and vulnerable plant and animal species, changes in the landscape and the beauty of landscapes, land, ie. Changing physical and chemical properties of soil, as well as microbiological composition, climate and microclimate and water balance (roughly disruption of hydrological regime, reducing water supplies and of flooding), and reduces recreational importance of the forest.

Current knowledge and experience are a basis for future efforts on combat wildfires. Its activities is necessary to continue and improve them in order to preserve bio-ecological, economic, commercial and social functions at the local, national and global levels.

Until today were conducted many scientific and technical researchs and the results of forestry experts must find a place in the education of firefighters and the implementation of the preventive and curative systems forest fires (combustible material, models of potential fire risk, models of spread of fires, etc.). 


\section{CONCLUSIONS - Zaključci}

The problem of spread of fires and protection of forest from depends on many factors and the resultant of their work, as a starting point for planning and carrying out technical and biological measures of prevention, the organization monitoring and fire detection systems, personnel and resources for fighting, their operational capacity, the implementation of educational, promotional and other measures.

This study found that the most important preventive measures that will help prevent spread of fires, and they are certainly daily education of the local population and employees in forestry, and through breeding measures, growing mixed stands to increase resistance to fire, and if they occur in broadleave forests fire damage are far less.

Through education of young people is actively acts on prevent the occurrence of fires, because the results of these studies show that the largest number of fires and burned areas most commonly is reported during the cleaning of agricultural cultures, and that these fires were not controlled, after which they spread to forests and forest lands.

Knowing the silvicultural and of the management measures, which type and volume depend on the type of forests, we create the essential preconditions for successful fire suppression, and directly and indirectly reduce the negative impact of certain factors, thus reducing the vulnerability of forest ecosystems.

Way of the organization of observation-alarming service, selection of equipment, means and methods of fire fighting is the basis problem of forests from fire. The complexity of the problem of fires and forest protection against them requires the involvement and interest of foresters, forest enthusiasts and all other members of the community. In order to protect forests from fires are necessary first of all forestry experts which deal with the problem of fires, their fire fighting, as well as experts and scientists involved in research work for this purpose.

\section{REFERENCES - Literatura}

DIMITROV, T. (1994): Biološki parametri prikladni za poboljšanje indeksa opasnosti od šumskih požara. Šumarski list, str. 105-111. Zagreb.

DIMITROV, T. (2000): Budući požari u odnosu na globalno zatopljenje. Šumarski list, br. 3-4., str. 203-209. Zagreb.

DUCIĆ, V., MILENKOVIĆ, M., RADOVANOVIĆ, M. (2007): Geografski faktori nastanka šumskih požara u Deliblatskoj Peščari, zbornik radova, Beograd.

FLOLLIOTT, P.F. (1988): Opportunites for Fire Menagment in the Future. Proceedings of the Symposium Effects of Fire Menagment of Southwestern Natural Resources, General Tehnikal Report, RM-191, Rocky Montain Forest and range Experiment Station, Fort Collins, Colorado, str.152.

GLAVAŠ, M. (2003): Šumski požari i protupožarna zaštita na području uprave šuma podružnice Senj od 1994-2003. godine, Šumarski list, 79-91, Zagreb. 
GLAVAŠ, M. (2005): Šumski požari u Republici Hrvatskoj, rad u pripremi - Šumarski fakultet Zagreb.

JURJEVIĆ, P., TOLIĆ, I. (2004): „Šumske prosjeke nisu zapreka za požare“, Hrvatsko šumarsko društvo, Šumarski list $1-2$; str. 55-61.

JURJEVIĆ, P., VULETIĆ, D., GRAČAN, J. (2009): „Šumski požari u Republici Hrvatskoj“, Hrvatsko šumarsko društvo, Šumarski list 1-2; str. 63-72.

KÜHRT, E., KNOLLENBERG, J., MERTENS, V. (2001): An automatic early warning system for forest fires, Annals of Burns and Fire Disasters - vol.XIV - n. 3 September 2001.

MAMUT M. (2011): Veza prirodnogeografske i sociogeografske osnove Dalmacije s ugroženošću otvorenog prostora požarom, Šumarski list, 1-2, CXXXV, 37-50, Zagreb.

MARGALETIĆ, J., MARGALETIĆ, M. (2003): Požari u šumi i na šumskom zemljištu kao čimbenici degradacije staništa, Zagreb.

MLADINEO, N., KNEZIĆ, S., BUZOLIĆ, J. (2001): Protupožarna zaštita korištenjem GIS podrške i protupožarnih senzora. Vatrozaštita,protuprovala i videonadzor, Zbornik radova, Šibenik, 1-8.

NETOLICKI, A., BLAŽEVIĆ, T., ANTOLOVIĆ, A. (2012): Višekriterijska analiza rizika od požara u Splitsko-dalmatinskoj županiji, Kig br.17, Vol. 1.

NIKOLOV, N. (2006): „Report on fires in the Balkan Region“; FAO Forestry Department, Rome, Italy; str. 1-24.

NODILO, J. (2003): Požari otvorenog prostora otoka i priobalja - slučajnost ili logičan slijed događaja?, Šum. list, (3-4), 171-176, Zagreb.

PYNE, J., PATRICIA, L., ANDREW D.L., RICHARD, D. L. (1996): Introduction to Wildland Fire, second edition, John Wiley \& Sons, Inc. New York.

ROSAVEC, R., DOMINIKO, D., BARČIĆ, D.,STAREŠNIĆ, D., ŠPANJOL, Ž., BILJAKOVIĆ, K., OŽURA, M., MARKOVIĆ, N., BOGNOLO, D. (2009): Analiza raspodjele površina zahvaćenih šumskim požarom na otocima Braču, Korčuli i Rabu, Šumarski list br. 5-6, CXXXIII (2009), str. 301-307, Zagreb.

ŠPANJOL, Ž., ROSAVEC, R., BARČIĆ, D., GALIĆ, I. (2011): Zapaljivost i gorivost sastojina alepskog bora (Pinus halepensis Mill.), Croat. j. for. eng. 32 (2011), str. 121-129, Zagreb.

USČUPLIĆ, M. (2001): Šumski požari u Bosni i Hercegovini i evaulacija šteta. Radovi Šumarskog fakulteta u Sarajevu. No 1, 2001. (7-17) Sarajevo.

VESELINOVIĆ, M., MILENKOVIĆ, S. (2007): Prevencija šumskih požara, Priručnik za edukaciju trenera, Institut za šumarstvo, Beograd.

VULETA, E. (2001): Šumski požari u Republici Hrvatskoj u razdoblju od 1996. do 2000. godine. Diplomski rad. Šumarski fakultet Sveučilišta u Zagrebu, 1-35.

WHELAN, R. J. (1995): The Ecology of Fire. - Cambridge University Press. 


\section{SAŽETAK}

Ugroženost šuma i šumskog zemljišta na području Federacije BiH je rezultat različitih aktivnosti kao što su: šumski požari, biljne bolesti i štetočine, neplanska i nezakonita sječa šuma, eksploatacija mineralnih resursa, hidro-akumulacije, klizišta kao i kontaminacija minama.

Od svih vrsta koje se javljaju na području $\mathrm{BiH}$, četinari su najviše ugroženi od šumskih požara. Za četinarske šume Bosne i Hercegovine se općenito danas može reći da su vrlo lošeg zdravstvenog stanja. Na pojedinim užim lokalitetima zdravstveno stanje naših šuma je toliko narušeno da prijeti njihovoj destabilizaciji i devastaciji, a kao posljedica toga su i šumski požari, koji najčešće zahvataju dio Hercegovine.

Šumski požari izazivaju velike štete, pogotovo u tek podignutim sastojinama i mladim kulturama, jer dolazi do uništenja sadnog materijala, kao i zemljišta na opožarenoj površini, pa su takva zemljišta skoro pa nepovratno uništena.

Za bosanskohercegovačke prilike šumski požari imaju specijalni značaj. Oni su u toku vegetacionog perioda kod nas gotovo redovna i svakodnevna pojava i potrebno im je posvetiti što više vremena, u smanjenju njihovog nastanka, kako kroz obrazovanje radnika koji gazduju šumama, tako i lokalnog stanovništva, koji načešće svojom nepažnjom uzrokuju nastajanje požara.

Istraživanjima koja su predmet ovog rada izvršena je analiza obima šumskih požara u periodu 2009-2013 godine na području općine Konjic.

Da bi se realizovao drugi zadatak istraživanja, a to je utvrđivanje intenziteta šumskih požara (petogodišnji period, 2009-2013 godine) na području općine Konjic registrovani su podaci prema vrsti požara, tipu šuma i zemljišta, te gazdinskim klasama na kojim su se ti požari javili, zatim uzroci nastanka požara.

Provedenom analizom na ovom području u periodu 2009-2013 godine zabilježeno je 37 požara. Od tog broja 20 požara su bili iz kategorije visokih i 17 niskih požara. Najveći broj požara bio je u 2011 godini 14, sa 310 ha opožarene površine, dok je najmanji broj zabilježen 2010 godine, svega tri požara, a opožarena površina iznosila je 7 ha.

Posmatrano prema rezultatima istraživanja može se vidjeti da je veći broj prizemnih u odnosu na visoke požare. Međutim, opožarena površina je znatno veća nastala štetnim djelovanjem visokih požara. Posmatrano prema godinama štetnog djelovanja šumskih požara uočava se da je najveći broj prizemnih zabilježen u 2011 godini a u 2012 godini registrovani su samo visoki požari.

Veliki je broj faktora koji utiču na pojavu požara, a među njima svakako je tip šume, odnosno njen uzgojni oblik u kome se oni javljaju. Prema rezultatima istraživanja najveći broj požara a posmatrano prema tipu vegetacije zabilježen je u četinarskim šumama ukupno 12. Od tog broja, 5 je u kategoriji prizemnih i 7 visokih požara. Značajan broj požara registrovan je u kategoriji niskih (izdanačkih) šuma ukupno 8, odnosno 7 prizemnih i jedan visoki.

Najveći broj požara je uzrokovan nepažnjom (ukupno 26 požara), dok je najviše površine opožareno namjernom paljevinom (3985,90 ha). Istraživanjem je utvrđeno da 
najveći broj požara je uzrokovan poljoprivrednim radovima, kao i veličina opožarene površine, najčešće u proljetnom periodu prilikom čišćenja poljoprivrednog zemljišta od strane lokalnog stanovništva.

Dosadašnja saznanja i iskustvo su osnov budućeg nastojanja na suzbijanju šumskih požara. Sa započetim aktivnostima potrebno je i dalje nastaviti te ih poboljšati i usavršiti u cilju očuvanja biološko-ekoloških, ekonomsko-gospodarskih i socijalnih funkcija na lokalnom, nacionalnom i globalnom nivou.

Corresponding author: Samir Alikadić; Forestry „Prenj“ d.d. Konjic, Bosnia and Herzegovina; e-mail:prenj@bih.net.ba 